\title{
KEEFEKTIFAN MODEL PEMBELAJARAN PICTURE AND PICTURE DAN MAKE A MATCH DITINJAU DARI HASIL BELAJAR DALAM PEMBELAJARAN IPA KELAS 4 SD GUGUS MAWAR - SURUH
}

\author{
Mawardi \& Desty Lusia Sari \\ mawardiu@gmail.com \\ Pendidikan Guru Sekolah Dasar - FKIP - UKSW Salatiga
}

\begin{abstract}
ABSTRAK
Pembelajaran IPA adalah ilmu yang mempelajari peristiwa di alam dengan melakukan observasi, eksperimentasi, penyimpulan agar siswa mempunyai pengetahuan yang diperoleh dari pengalaman melalui serangkaian proses ilmiah yaitu penyelidikan, penyusunan dan penyajian gagasan. Model pembelajaran Picture and Picture dan Make a Match adalah model pembelajaran yang menjadi solusi permasalahan pembelajaran IPA yang masih bersifat hafalan. Tujuan penelitian ini adalah untuk mengetahui ada atau tidaknya perbedaan keefektifan yang signifikan antara model pembelajaran Picture and Picture dan Make a Match ditinjau dari hasil belajar IPA kelas 4 SD gugus Mawar Suruh. Penelitian yang dilakukan adalah penelitian eksperimen jenis quasi experiment dengan desain Nonequivalent Control Group Design. Hasil uji kesetaraan pada kelompok eksperimen dan kontrol menunjukkan adanya kesamaan. Teknik pengumpulan data menggunakan tes dan observasi. Populasi pada penelitian ini adalah gugus Mawar Suruh dan sampelnya siswa kelas 4 SDN Plumbon 01, SDN Plumbon 04, dan SDN Kebowan 02. Teknik analisis data yang dipakai untuk menguji skor hasil belajar siswa adalah uji t dengan teknik Independent Sample t- Test. Hasil penelitian yang telah dilakukan menunjukkan bahwa tidak terdapat perbedaan yang signifikan model pembelajaran Picture and Picture dan Make a Match ditinjau dari hasil belajar IPA pada SD gugus Mawar Suruh. Hal tersebut dapat dibuktikan setelah dilakukan uji t posttest yang menunjukkan bahwa nilai t hitung dan $\mathrm{t}$ tabel adalah 0,538 dan 1,994 dengan sig. (2-tailed) adalah 0,592.
\end{abstract}

Kata kunci: Picture and Picture, Make a Match, Pembelajaran IPA

\section{PENDAHULUAN}

Ilmu Pengetahuan Alam merupakan mata pelajaran di SD yang dimaksudkan agar siswa mempunyai pengetahuan, gagasan, dan konsep yang terorganisasi tentang alam sekitar, yang diperoleh dari pengalaman melalui serangkaian proses ilmiah antara lain penyelidikan, penyusunan, dan penyajian gagasan-gagasan. IPA (Ilmu Pengetahuan Alam) merupakan pengetahuan yang berhubungan dengan cara mencari tahu tentang alam secara sistematis, sehingga 
IPA bukan hanya penguasaan kumpulan pengetahuan yang berupa fakta-fakta, konsep-konsep, atau prinsi-prinsip saja, tetapi juga merupakan suatu proses penemuan (Sulistyorini, 2007: 39). Perlu diciptakan kondisi pembelajaran IPA di SD dapat mendorong siswa untuk aktif dan ingin tahu. Dengan demikian, pembelajaran IPA merupakan kegiatan mencari tahu terhadap permasalahan alam di sekitarnya. Guru bukan hanya dituntut untuk memiliki pengetahuan, keterampilan mengajar dengan kompleksitas peranan sesuai dengan tugas dan fungsi yang diembannya, tetapi juga harus dapat kreatif. Upaya dalam melaksanakan tugasnya meningkatkan kualitas hasil pendidikan amat tergantung pada kemampuan guru untuk mengembangkan kreativitasnya.

Kenyataannya pada saat peneliti melakukan studi pendahuluan dengan guru kelas 4 Ibu Sri Hardati di SD inti dari gugus mawar SDN Plumbon 01 Kecamatan Suruh Kabupaten Semarang belum menggunakan model-model pembelajaran kreatif dalam pembelajaran IPA di kelas. Hal tersebut dikarenakan menurut Ibu Sri Hardati lupa akan nama-nama model pembelajaran, yang terpenting adalah beliau mengajar dan membuat siswa paham akan materi yang sedang diajarkan. Meskipun dalam pembelajarannya tersebut Ibu Sri Hardati belum menggunakan model-model pembelajaran kreatif, tetapi sudah menggunakan alat peraga yang sudah tersedia di sekolah, melakukan tanya jawab antara guru dan siswa, guru melakukan demonstrasi, menggunakan benda-benda nyata sesuai dengan materi yang sedang dipelajari. Apabila dari sekolah belum tersedia alat peraga maka guru meminta siswa untuk membawa dari rumah tetapi yang tidak memberatkan siswa itu sendiri. Dalam proses belajar mengajar beberapa siswa dapat aktif mengikuti pembelajaran dengan bimbingan guru, tetapi ada juga yang masih pasif karena malu menyampaikan pendapatnya atau takut salah.

Hasil wawancara dengan Ibu Sri Hardati selaku guru kelas 4 SDN Plumbon 01 Kecamatan Suruh Kabupaten Semarang, diperoleh data hasil belajar siswa kelas 4A semester 2 dalam mata pelajaran IPAadalah nilai tertinggi siswa 100 dan nilai terendahnya adalah 50. Sedangkan nilai rata-rata dari kelas 4A dalam mata pelajaran IPA adalah 78,68. Dari data yang peneliti peroleh batas KKM (Kriteria Ketuntasan Minimal) dari kelas 4 adalah 64. Hasil belajar IPA kelas 4A di SDN Plumbon 01 Kecamatan Suruh Kabupaten Semarang menunjukkan $11 \%$ siswa masih di bawah KKM dan 89\% siswa sudah di atas KKM. Berdasarkan wawancara dengan Bapak Yasak, selaku kepala sekolah SDN Plumbon 01 Kecamatan Suruh Kabupaten Semarang, KKM (Kriteria Ketuntasan Minimal) dapat ditentukan dari Indikator, keadaan siswa di SDN Plumbon 01, Kompleksitas terhadap materi yang bersangkutan, dan daya dukung lainnya.

Selain peneliti melakukan observasi di SD inti SDN Plumbon 01, peneliti juga melakukan observasi di SD imbas gugus Mawar SDN Plumbon 04, Kecamatan Suruh, Kabupaten Semarang. Dari hasil wawancara dengan Ibu Sunarsih selaku 
guru kelas 4 SDN Plumbon 04, bahwa dalam pembelajarannya Ibu Sunarsih belum menggunakan model pembelajaran sama sekali. Selain belum menggunakan metode atau model pembelajaran, Ibu Sunarsih hanya menjelaskan, melakukan tanya jawab, dan melakukan penugasan kepada siswa pada waktu melakukan proses belajar mengajar di kelas. Selama proses belajar mengajar berlangsung, banyak siswa yang belum aktif dalam mengikuti pembelajaran. Hal tersebut bisa terjadi karena guru hanya terlalu fokus untuk menjelaskan materi dengan ceramah saja.

Hasil wawancara dengan Ibu Sunarsih selaku guru kelas 4 SDN Plumbon 04, Kecamatan Suruh, Kabupaten Semarang, diperoleh data hasil belajar siswa kelas 4 semester 2 dalam mata pelajaran IPA adalah nilai tertingginya 90 dan nilai terendahnya 50. Sedangkan nilai rata-rata kelas 4 dalam mata pelajaran IPA adalah 68,53. Dari data yang peneliti peroleh batas KKM (Kriteria Ketuntasan Minimal) dari kelas 4 adalah 64. Hasil belajar IPA kelas 4 di SDN Plumbon 04 Kecamatan Suruh, Kabupaten Semarang, menunjukkan 24\% siswa masih di bawah KKM dan $76 \%$ siswa sudah di atas KKM.

Guna meningkatkan partisipasi dan keaktifan siswa di dalam kelas, guru dapat menerapkan berbagai model pembelajaran dalam setiap mata pelajaran, konsep materi dan tujuan yang ingin dicapai berbeda-beda. Dalam pemahaman konsep-konsep materi diperlukan model pembelajaran yang dapat membuat siswa benar-benar aktif dan merasakan suasana yang menyenangkan saat belajar. Ada berbagai model pembelajaran kreatif yang cocok untuk mengetahui kemampuan siswa dalam mencapai kompetensi IPA, termasuk juga model pembelajaran Picture and Picture dan Make a Match.

Beberapa hasil penelitian yang ditemukan menunjukkan bahwa model pembelajaran Picture and Picture dan model pembelajaran Make a Match efektif untuk diterapkan dalam pembelajaran di Sekolah Dasar. Namun masih belum dapat menunjukkan salah satu model mana yang lebih efektif untuk pembelajaran IPA. Oleh sebab itu, peneliti ingin mengetahui keefektifan model pembelajaran Picture and Picture dan model pembelajaran Make a Match dalam pembelajaran IPA kelas 4 Sekolah Dasar. Apakah terdapat perbedaan yang signifikan model pembelajaran Picture and Picture dan model pembelajaran Make a Match apabila diterapkan dalam pembelajaran IPA kelas 4 Sekolah Dasar.

\section{KAJIAN PUSTAKA}

\section{Hakikat Ilmu Pengetahuan Alam}

Ilmu Pengetahuan Alam adalah pengetahuan yang rasional dan objektif tentang alam semesta dengan segala isinya (Samatowa, 2010: 2). Selain itu, Nash (dalam Samatowa, 2010: 3) menyatakan bahwa IPA itu adalah suatu cara atau metode untuk mengamati alam. Nash juga menjelaskan bahwa cara IPA mengamati 
dunia ini bersifat analisis, lengkap, cermat, serta menghubungkannya antara suatu fenomena dengan fenomena lain, sehingga keseluruhannya membentuk suatu perspektif yang baru tentang objek yang diamatinya.

Wahyana (dalam Trianto, 2014:136) mengatakan bahwa IPA adalah suatu kumpulan pengetahuan tersusun secara sistematik dan dalam penggunaannya secara umum terbatas pada gejala-gejala alam.

Dari beberapa pendapat di atas dapat disimpulkan bahwa IPA adalah ilmu yang mempelajari peristiwa-peristiwa yang terjadi di alam dengan melakukan observasi, eksperimentasi, penyimpulan, penyusunan teori agar siswa mempunyai pengetahuan, gagasan dan konsep yang terorganisasi tentang alam sekitar, yang diperoleh dari pengalaman melalui serangkaian proses ilmiah antara lain penyelidikan, penyusunan dan penyajian gagasan-gagasan.

Adapun tujuan pembelajaran IPA di sekolah dasar dalam Badan Nasional Standar Pendidikan (Susanto, 2013: 171), dimaksudkan untuk:

1. Memperoleh keyakinan terhadap kebesaran Tuhan Yang Maha Esa berdasarkan keberadaan, keindahan, dan keteraturan alam ciptaan-Nya.

2. Mengembangkan pengetahuan dan pemahaman konsep-konsep IPA yang bermanfaat dan dapat diterapkan dalam kehidupan sehari-hari.

3. Mengembangkan rasa ingin tahu, sikap positif dan kesadaran tentang adanya hubunganyang saling memengaruhi antara IPA, lingkungan, teknologi, dan masyarakat.

4. Mengembangkan keterampilan proses untuk menyelidiki alam sekitar, memecahkan masalah,dan membuat keputusan.

5. Meningkatkan kesadaran untuk berperan serta dalam memelihara, menjaga, dan melestarikan lingkungan alam.

6. Meningkatkan kesadaran untuk menghargai alam dan segala keteraturannya sebagai salah satu ciptaan Tuhan.

7. Memperoleh bekal pengetahuan, konsep, dan keterampilanIPA sebagai dasar untuk melanjutkan pendidikan ke SMP.

Seperti yang telah diuraikan bahwa IPA mencakup pengetahuan tentang sains untuk mencapai tujuan pembelajaran IPA seperti yang dijabarkan di atas, maka dalam pembelajaran IPA memerlukan model pembelajaran. Ada beberapa pakar yang mendefinisikan model pembelajaran, beberapa diantaranya adalah Joyce \& Weil (dalam Rusman, 2011: 133) berpendapat bahwa model pembelajaran adalah suatu rencana atau pola yang dapat digunakan untuk membentuk kurikulum (rencana pembelajaran jangka panjang), merancang bahan-bahan pembelajaran, dan membimbing pembelajaran di kelas atau yang lain. Model pembelajaran dapat dijadikan pola pilihan, artinya guru dapat memilih model pembelajaran yang sesuai dan efisien untuk mencapai tujuan pendidikannya. 
Menurut Eggen dan Kauchak (dalam Hosnan, 2014: 234) bahwa model pembelajaran adalah pedoman berupa program atau petunjuk strategi mengajar yang dirancang untuk mencapai suatu pembelajaran. Pedoman ini memuat tanggung jawab guru dalam merencanakan, melaksanakan, dan mengevaluasi kegiatan pembelajaran. Jadi, model pembelajaran adalah strategi yang digunakan oleh guru untuk meningkatkan motivasi belajar siswa melalui suatu ide atau gagasan dari guru kepada siswa.

Menurut peneliti model yang cocok diterapkan untuk pembelajaran IPA adalah model pembelajaran Picture and Picture dan model pembelajaran Make a Match. Kedua model tersebut cocok diterapkan dalam pembelajaran IPA karena dalam model tersebut menuntut siswa untuk aktif, berfikir kritis, percaya diri dalam mengkomunikasikan hasil kerjanya. Sedangkan dalam pembelajaran IPA siswa juga dituntut untuk aktif, berfikir kritis, percaya diri dalam mengkomunikasikan hasil kerjanya dalam mengembangkan pengetahuannya tentang sains. Dengan digunakannya model Picture and Picture dan Make a Match dalam pembelajaran IPA maka siswa dapat berperan aktif, berfikir kritis, percaya diri dalam mengkomunikasikan hasil kerjanya melalui pengurutan gambar-gambar yang disediakan dan menjodohkan kartu sesuai pasangan soal dan jawabannya. Sebelumnya siswa diajak untuk bereksperimen membuat kincir angin dari kertas, dan berdiskusi bersama kelompok. Setelah itu siswa menyampaikan hasil kerjanya di depan kelas dan itu termasuk siswa mengkomunikasikan materi. Dengan begitu diharapkan siswa akan lebih memahami pembelajaran IPA materi berbagai energi alternatif dan cara penggunaannya. Berikut penjelasan mengenai model pembelajaran Picture and Picture dan Make a Match.

\section{Model Pembelajaran Picture and Picture}

Model pembelajaran Picture and Picture adalah suatu pembelajaran yang mengguanakan gambar dipasangkan/diurutkan menjadi urutan logis (Hamdani, 2011: 89). Pembelajaran ini memiliki ciri aktif, inovatif, kreatif, dan menyenangkan. Pembelajaran ini mengandalkan gambar sebagai media dalam proses pembelajaran. Gambar-gambar ini menjadi faktor utama dalam proses pembelajaran.

Menurut Suprijono (2009: 129), model pembelajaram Picture and Picture adalah suatu model yang menggunakan gambar dan dipasangkan atau diurutkan menjadi bentuk dan urutan yang logis. Model Pembelajaran ini mengandalkan gambar sebagai media dalam proses pembelajaran. Gambar-gambar ini menjadi faktor utama dalam proses pembelajaran. Jadi dengan media gambar tersebut siswa lebih dapat memahami pembelajaran IPA materi mengenai energi alternatif, karena dengan model tersebut siswa dapat berperan aktif dalam mengurutkan gamabar 
yang sudah diacak dan mengkomunikasikannya di depan kelas. Langkah-langkah Picture and Picture dalam Hosnan (2014: 256) adalah:

1. Guru menyampaikan kompetensi yang ingin dicapai.

2. Menyajikan materi sebagai pengantar.

3. Guru menunjukkan/memperlihatkan gambar-gambar kegiatan berkaitan dengan materi.

4. Guru menunjuk/memanggil siswa secara bergantian memasang/mengurutkan gambar-gambar menjadi urutan yang logis.

5. Guru menanyakan alasan/dasar pemikiran urutan gambar tersebut.

6. Dari alasan/urutan gambar tersebut guru memulai menanamkan konsep/materi sesuai dengan kompetensi yang ingin dicapai.

7. Kesimpulan/rangkuman.

Model pembelajaran Picture and Picture sangat mudah diterapkan di dalam kelas. Secara garis besar langkahnya meliputi: sebelum pembelajaran dimulai guru menyampaikan tujuan pembelajaran, guru memberikan materi pengantar, menyajikan gambar-gambar pada setiap kelompok sesuai materi, menunjuk setiap untuk memasangkan gambar, meminta perwakilan setiap kelompok untuk mengurutkan gambar sesuai urutannya, menanamkan konsep materi, guru dan siswa membuat kesimpulan bersama. Selain model Picture and Picture, peneliti juga menggunakan model Make a Match dalam pembelajarannya. Berikut penjelasan dari model Make a Match .

Model Make a Match yaitu model pembelajaran yang dilakukan dengan menjodohkan kartu soal dan jawaban sesuai kartu yang dipegang masing-masing siswa. Melalui pembelajaran model Make a Match, memberikan kesempatan siswa untuk meningkatkan pemahaman mengenai materi sehingga siswa dapat menentukan pasangan yang tepat dari kartu-kartu yang diperolehnya. Setelah itu siswa dapat mengkomunikasikan di depan kelas bersama pasangan masing-masing. Selain pengertian, model pembelajaran Make a Match memiliki beberapa langkahlangkah. Menurut Rusman (2013: 223), menjelaskan langkah-langkah kegiatan menggunakan model pembelajaran Make a Match yaitu sebagai berikut:

1. Guru menyiapkan beberapa kartu yang berisi beberapa konsep/topik yang cocok untuk sesi review (satu sisi kartu berupa kartu soal dan sisi sebaliknya berupa jawaban).

2. Setiap siswa mendapatkan satu kartu dan memikirkan jawaban atau soal dari kartu yang dipegang.

3. Siswa mencari pasangan yang mempunyai kartu yang cocok dengan kartunya (kartu soal/kartu jawaban).

4. Siswa yang dapat mencocokkan kartunya sebelum batas waktu diberi poin.

5. Setelah satu babak kartu dikocok lagi agar tiap siswa mendapat kartu yang berbeda dari sebelumnya, demikian seterusnya. 


\section{Kesimpulan.}

Model pembelajaran Make a Match sangat mudah diterapkan di dalam kelas. Secara garis besar langkahnya meliputi: sebelum pembelajaran dimulai dari penyampaian materi, pembagian kelompok soal dan jawaban, pembagian masingmasing kartu soal dan jawaban, penyampaian dalam mencocokkan kartu yang dipegang, mencari pasangan masing-masing, laporan hasil kerja, dan konfirmasi.

Berdasarkan permasalahan dan kajian teoritik seperti telah diuraikan di atas, maka disusun kerangka pikir eksperimen yaitu sebagai berikut. Pembelajaran IPA menuntut siswa untuk dapat belajar dalam pengamatan lingkungan sekitar sehingga dapat diterapkan di dalam kehidupannya sehari-hari. Selain itu siswa juga membutuhkan suatu teknik belajar yang dapat membantu siswa memahami konsepkonsep penting dalam pembelajaran IPA. Melalui model pembelajaran Picture and Picture dan Make a Match diharapkan siswa lebih mudah memperoleh informasi dan memahami materi karena siswa aktif dalam pembelajaran melalui kerja sama dalam kelompok. Selain itu siswa juga dapat berbagi informasi dengan teman satu kelompok maupun kelompok lain melalui laporan diskusi masing-masing kelompok.

Model pembelajaran Picture and Picture memiliki beberapa sintak yang sudah dijabarkan yaitu mulai dari penyampaian tujuan pembelajaran yang disampaikan guru agar siswa dapat mengukur sejauh mana kemampuannya dalam memahami materi. Setelah tujuan pembelajaran disampaikan, guru menjelaskan materi pengantar agar siswa dapat mengiuti pembelajaran dengan model Picture and Picture dengan baik. Guru menunjukan gambar yang akan digunakan dalam pembelajaran, agar siswa dapat mengemukakan pendapatnya mengenai gambar tersebut. Siswa mengurutkan gambar prosespemanfaatan energi alternatif bersama kelompoknya. Setelah selesai mengurutkan gambar, siswa memberikan alasan dalam pengurutan gambar tersebut. Dari tahap tersebut siswa dituntut untuk aktif dalam pembelajaran. Setelah alasan disampaikan siswa maka guru dan siswa dapat memberikan kesimpulan dari pembelajaran yang dilakukan. Jadi kesimpulan dari penjelasan tersebut dari guru menjelaskan materi, menunjukkan gambar, meminta siswa untuk aktif dalam mengurutkan gambar pada bagan, dan memberikan kesimpulan bersama.

Model pembelajaran Make a Match juga mempunyai beberapa sintak yaitu mulai dari penyampaian materi pembelajaran yang disampaikan guru agar siswa dapat memahami maksud dari materi yaitu sumber energi alternatif dan cara penggunaannya. Setelah itu siswa dibagi menjadi 2 kelompok yaitu satu kelompok mendapatkan kartu soal dan satu kelompok lainnya mendapatkan kartu jawaban. Guru menyampaikan cara mencocokkan kartu soal dan jawaban tersebut dengan mencari pasangan, diharapkan siswa dapat memahami materi dengan mengetahui soal atau jawaban sesuai kartu yang dipegang. Setelah setiap siswa menemukan 
pasangan masing-masing, misalnya siswa yang mendapat kartu soal menemukan siswa yang mendapat kartu jawaban setiap pasangan menyampaikan hasil kerjanya di depan kelas. Setelah penyampaian hasil kerja sudah selesai, guru melakukan konfirmasi mengenai kebenaran soal dan jawaban. Hal tersebut dilakukan agar semua siswa mengetahui kebenaran soal dan jawabannya. Setelah itu setiap pasangan menempelkan kartu pada benang yang sudah disediakan agar siswa juga melatih kepercayaan dirinya. Berdasarkan penjelasan tersebut siswa sama-sama berperan aktif dalam pembelajaran, maka dengan menggunakan model pembelajaran Picture and Picture dan Make a Match diharapkan dapat berpengaruh positif terhadap hasil belajar siswa.

Berdasarkan kajian pustaka dan kerangka pikir di atas, maka hipotesis penelitian ini adalah sebagai berikut.

$\mathrm{H}_{0}$ : Tidak terdapat perbedaan hasil belajar IPA yang signifikan dalam penerapan model pembelajaran Picture and Picture dan model pembelajaran Make a Match pada siswa SD kelas 4 gugus Mawar, Kecamatan Suruh, Kabupaten Semarang.

$\mathrm{H}_{\mathrm{a}}$ : Terdapat perbedaan hasil belajar IPA yang signifikan dalam penerapan model pembelajaran Picture and Picture dan model pembelajaran Make a Match pada siswa SD kelas 4 gugus Mawar, Kecamatan Suruh, Kabupaten Semarang.

\section{METODE PENELITIAN}

Subyek penelitian dalam penelitian ini adalah populasi dari SD Gugus Mawar suruh yang terdapat 5 Sekolah Dasar, peneliti mengambil kelas 4 dari 3 SD sebagai sampel penelitian yaitu kelas 4A dan 4B SDN Plumbon 01, kelas 4 SDN Plumbon 04, dan kelas 4 SDN Kebowan 02. Penelitian ini mengambil lokasi di SD inti yaitu SDN Plumbon 01 dan SD imbas yaitu SDN Plumbon 04 dan SDN Kebowan 02, Gugus Mawar, Kecamatan Suruh, Kabupaten Semarang. Kegiatan penlitian ini dilaksanakan pada bulan April 2015 pada semester genap. Penelitian ini sendiri menggunakan penelitian eksperimen, yaitu jenis Quasi Experimental Design dengan desain penelitian yaitu Nonequivalent Control Group Design. Variabel dalam penelitian ini yaitu terdapat variabel X dan variabel Y. Variabel X dalam penelitian ini adalah model pembelajaran Picture and Picture dan model pembelajaran Make a Match. Teknik dan Instrumen pengumpulan data menggunakan tes pretest dan posttest dan dilakukan observasi kelas dan wawancara guru.

Uji coba instrumen dalam penelitian ini adalah menggunakan uji validitas soal dan uji reliabilitas soal tes. Sebelum penelitian ini dilakukan ada beberapa syarat yang harus dilakukan yaitu melakukan uji homogenitas untuk mengetahui apakah kelas yang digunakan untuk penelitian tersebut homogen dan uji normalitas 
varian data. Setelah itu dilakukan uji hipotes untuk menguji signifikasi perbedaan mean antara kelompok eksperimen dan kelompok kontrol analisis data yang digunakan adalah uji t-test. Uji t-test digunakan untuk menguji signifikasi perbedaan mean antara kelas eksperimen dan kelas kontrol. Uji t-test yang digunakan adalah uji dua sampel tidak berhubungan (Independent Samples T Test.). Hipotesis statistik dapat dirumuskan sebagai berikut:

1. $\mathrm{H}_{0}: \mu_{1}=\mu_{2}$ artinya tidak terdapat perbedaan yang signifikan antaramodel pembelajaran Picture and Picture dan model pembelajaran Make a Match ditinjau dari hasil belajar IPA kelas 4 SD semester 2 tahun ajaran 2014/2015.

2. $\mathrm{H}_{\mathrm{a}}: \mu_{1} \neq \mu_{2}$ artinya terdapat perbedaan yang signifikan antaramodel pembelajaran and Picture dan model pembelajaran Make a Match ditinjau dari hasil belajar IPA kelas 4 SD semester 2 tahun ajaran 2014/2015.

\section{HASIL PENELITIAN DAN PEMBAHASAN}

\section{Hasil Penelitian pada Implementasi Pembelajaran dengan Model Picture and Picture sebagai Kelompok Eksperimen}

Dalam hasil penelitian ini dipaparkan mengenai proses pembelajaran dan tingkat hasil belajar IPA yang dicapai dengan menggunakan perlakuan model Picture and Picture pada kelompok eksperimen di SD Negeri Plumbon 01 kelas 4A (SD Inti) dan SD Negeri Plumbon 04 (SD Imbas).

\section{Hasil Observasi Proses Pembelajaran IPA di Kelas 4A SD Negeri Plumbon 01 (SD Inti)}

Topik yang digunakan dalam penelitian ini adalah materi mengenai berbagai energi alternatif dan cara penggunaannya yang didasarkan pada Standar Kompetensi 8. Memahami berbagai bentuk energi dan cara penggunaannya dalam kehidupan sehari-hari, dan Kompetensi Dasar 8.2 Mengetahui berbagai energi alternatif dan cara penggunaannya.Sedangkan indikator pencapaian kompetensinya adalah menjelaskan pengertian energi alternatif, menyebutkan macam-macam sumber energi alternatif, memberikan contoh benda-benda yang menggunakan sumber energi alternatif dalam kehidupan sehari-hari, memberikan contoh pemanfaatan energi alternatif dalam kehidupan sehari-hari, dan menyebutkan kelebihan dan kekurangan energi alternatif.

Berdasarkan hasil observasi guru dalam melaksanakan pembelajaran yang sesuai sintak telah mencapai $82,76 \%$, sedangkan yang belum dilaksanakan sintaknya adalah mencapai $17,24 \%$. Sebenarnya guru telah melaksanakan pembelajaran sesuai sintak model pembelajaran Picture and Picture tetapi ada langkah-langkah lain yang belum dilaksanakan guru, maka hasil observasi belum mencapai $100 \%$. 
Sesuai dengan data yang diambil, bahwa nilai rata-rata kelas eksperimen (nilai pretest) sebelum proses pembelajaran dengan perlakuan model Picture and Picture sebesar 60,53 dengan standar deviasi 15,53622. Sedangkan setelah diberikan proses pembelajaran dengan perlakuan model Picture and Picture didapatkan nilai rata-rata (nilai posttest) meningkat menjadi 72,63 dengan standar deviasi 18,66134 . Hal lain yang tampak adalah nilai tertinggi yang dicapai pada pretest adalah 85 dan nilai terendahnya adalah 35. Sedangkan pada posttest nilai tertinggi yang berhasil dicapai adalah 95 dan nilai terendahnya adalah 25 . Jumlah siswa yang mengikuti pretest dan posttest ini sebanyak 19 siswa.

\section{Hasil Observasi Proses Pembelajaran IPA di Kelas 4 SD Negeri Plumbon 04 (SD Imbas)}

Topik yang digunakan dalam penelitian ini adalah materi mengenai berbagai energi alternatif dan cara penggunaannya yang didasarkan pada Standar Kompetensi 8. Memahami berbagai bentuk energi dan cara penggunaannya dalam kehidupan sehari-hari, dan Kompetensi Dasar 8.2 Mengetahui berbagai energi alternatif dan cara penggunaannya.Sedangkan indikator pencapaian kompetensinya adalah menjelaskan pengertian energi alternatif, menyebutkan macam-macam sumber energi alternatif, memberikan contoh benda-benda yang menggunakan sumber energi alternatif dalam kehidupan sehari-hari, memberikan contoh pemanfaatan energi alternatif dalam kehidupan sehari-hari, dan menyebutkan kelebihan dan kekurangan energi alternatif.

Berdasarkan hasil observasi guru dalam melaksanakan pembelajaran yang sesuai sintak telah mencapai $86,21 \%$, sedangkan yang belum dilaksanakan sintaknya adalah mencapai $13,79 \%$. Dalam pembelajaran ada beberapa sintak model pembelajaran Picture and Picture yang belum dilaksanakan oleh guru.Selain itu, ada langkah-langkah lain juga yang belum dilaksanakan guru, maka hasil observasi tersebut belum mencapai $100 \%$.

Sesuai dengan data yang diambil, bahwa nilai rata-rata kelas eksperimen (nilai pretest) sebelum proses pembelajaran dengan perlakuan model Picture and Picture sebesar 72,65 dengan standar deviasi 15,42296. Sedangkan setelah diberikan proses pembelajaran dengan perlakuan model Picture and Picture didapatkan nilai rata-rata (nilai posttest) meningkat menjadi 84,0625 dengan standar deviasi 10,83494 . Hal lain yang tampak adalah nilai tertinggi yang dicapai pada pretest adalah 95 dan nilai terendahnya adalah 45. Sedangkan pada posttest nilai tertinggi yang berhasil dicapai adalah 100 dan nilai terendahnya adalah 70. Jumlah siswa yang mengikuti pretest dan posttest ini sebanyak 16 siswa. 


\section{Hasil Penelitian pada Implementasi Pembelajaran dengan Model Make a Match sebagai Kelompok Kontrol}

Dalam hasil penelitian ini dipaparkan mengenai proses pembelajaran dan tingkat hasil belajar IPA yang dicapai dengan menggunakan perlakuan model Picture and Picture pada kelompok kontrol di SD Negeri Plumbon 01 kelas 4B (SD Inti) dan SD Negeri Kebowan 02 (SD Imbas).

\section{Hasil Observasi Proses Pembelajaran IPA di Kelas 4B SD Negeri Plumbon 01 (SD Inti)}

Topik yang digunakan dalam penelitian ini adalah materi mengenai berbagai energi alternatif dan cara penggunaannya yang didasarkan pada Standar Kompetensi 8. Memahami berbagai bentuk energi dan cara penggunaannya dalam kehidupan sehari-hari, dan Kompetensi Dasar 8.2 Mengetahui berbagai energi alternatif dan cara penggunaannya.Sedangkan indikator pencapaian kompetensinya adalah menjelaskan pengertian energi alternatif, menyebutkan macam-macam sumber energi alternatif, memberikan contoh benda-benda yang menggunakan sumber energi alternatif dalam kehidupan sehari-hari, memberikan contoh pemanfaatan energi alternatif dalam kehidupan sehari-hari, dan menyebutkan kelebihan dan kekurangan energi alternatif.

Berdasarkan hasil observasi guru dalam melaksanakan pembelajaran yang sesuai sintak telah mencapai 79,31\%, sedangkan yang belum dilaksanakan sintaknya adalah mencapai 20,69\%. Sebenarnya guru telah melaksanakan pembelajaran sesuai sintak model pembelajaran Make a Match tetapi ada langkahlangkah lain yang belum dilaksanakan guru, maka hasil observasi belum mencapai $100 \%$.

Sesuai dengan data yang diambil, bahwa nilai rata-rata kelas kontrol (nilai pretest) sebelum proses pembelajaran dengan perlakuan model Make a Match sebesar 53,61 dengan standar deviasi 12,34380. Sedangkan setelah diberikan proses pembelajaran dengan perlakuan model Make a Match didapatkan nilai rata-rata (nilai posttest) meningkat menjadi 70,88 dengan standar deviasi 11,62370. Hal lain yang tampak adalah nilai tertinggi yang dicapai pada pretest adalah 75 dan nilai terendahnya adalah 30 . Sedangkan pada posttest nilai tertinggi yang berhasil dicapai adalah 85 dan nilai terendahnya adalah 35 . Jumlah siswa yang mengikuti pretest 18 siswa dan posttestsebanyak 17 siswa.

\section{Hasil Observasi Proses Pembelajaran IPA di Kelas 4 SD Negeri Kebowan 02 (SD Imbas)}

Topik yang digunakan dalam penelitian ini adalah materi mengenai berbagai energi alternatif dan cara penggunaannya yang didasarkan pada Standar Kompetensi 8. Memahami berbagai bentuk energi dan cara penggunaannya dalam 
kehidupan sehari-hari, dan Kompetensi Dasar 8.2 Mengetahui berbagai energi alternatif dan cara penggunaannya.Sedangkan indikator pencapaian kompetensinya adalah menjelaskan pengertian energi alternatif, menyebutkan macam-macam sumber energi alternatif, memberikan contoh benda-benda yang menggunakan sumber energi alternatif dalam kehidupan sehari-hari, memberikan contoh pemanfaatan energi alternatif dalam kehidupan sehari-hari, dan menyebutkan kelebihan dan kekurangan energi alternatif.

Berdasarkan hasil observasi guru dalam melaksanakan pembelajaran yang sesuai sintak telah mencapai $82,76 \%$, sedangkan yang belum dilaksanakan sintaknya adalah mencapai $17,24 \%$. Sebenarnya guru telah melaksanakan pembelajaran sesuai sintak model pembelajaran Make a Match tetapi ada langkahlangkah lain yang belum dilaksanakan guru, maka hasil observasi belum mencapai $100 \%$.

Sesuai dengan data yang diambil, bahwa nilai rata-rata kelas kontrol (nilai pretest) sebelum proses pembelajaran dengan perlakuan model Make a Match sebesar 71,58 dengan standar deviasi 18,10867. Sedangkan setelah diberikan proses pembelajaran dengan perlakuan model Make a Match didapatkan nilai rata-rata (nilai posttest) meningkat menjadi 80,25 dengan standar deviasi 14,09320. Hal lain yang tampak adalah nilai tertinggi yang dicapai pada pretest adalah 90 dan nilai terendahnya adalah 35 . Sedangkan pada posttest nilai tertinggi yang berhasil dicapai adalah 100 dan nilai terendahnya adalah 50. Jumlah siswa yang mengikuti pretest 19 siswa dan posttest sebanyak 20 siswa.

\section{Deskripsi Komparasi Hasil Pengukuran}

Deskripsi komparasi ini memaparkan perbandingan hasil pengukuran dari kelompok eksperimen dan kelompok kontrol masing-masing SD (SD Inti dan SD Imbas) berdasarkan nilai pretest dan posttest. Deskripsi tersebut disajikan dalam bentuk grafik sebagai berikut.

Data yang telah diperoleh menunjukkan bahwa terdapat perbedaan nilai rata-rata tahap pengukuran awal yang ditunjukkan oleh adanya selisih skor antara kelompok eksperimen dan kelompok kontrol sebesar 6,92 dimana nilai rata-rata kelompok eksperimen lebih unggul. Sedangkan pada tahap pengukuran akhir juga terdapat perbedaan nilai rata-rata yang ditunjukkan adanya selisih skor antara kelompok eksperimen dan kelompok kontrol sebesar 1,75 dimana nilai rata-rata kelompok eksperimen lebih unggul.

Apabila dilihat dari hasil pengukuran pada tahap awal dan akhir, maka dapat diketahui gain score yang diperoleh yaitu sebesar 12,10 untuk kelompok eksperimen dan 17,27 untuk kelompok kontrol.

Secara ringkas deskripsi komparasi hasil pengukuran tersebut dapat dilihat pada gambar 1 berikut. 
Keefektifan Model Pembelajaran Picture And Picture dan Make A Match ditinjau dari Hasil Belajar dalam Pembelajaran IPA Kelas 4 SD Gugus Mawar - Suruh (Mawardi \& Desty Lusia Sari)

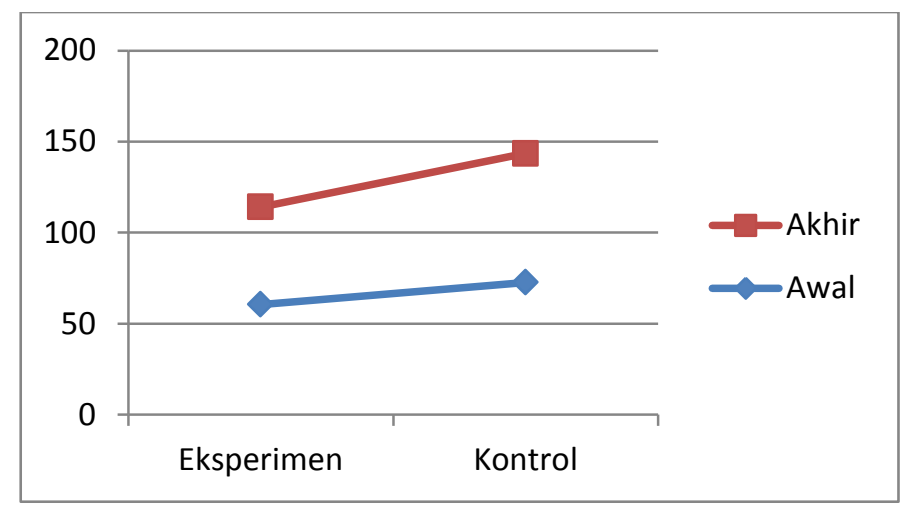

Gambar 1. Grafik Deskripsi Komparasi Hasil Pengukuran Kelompok Eksperimen dan Kelompok Kontrol SD Inti Gugus Mawar

Data yang telah diperoleh menunjukkan bahwa terdapat perbedaan nilai rata-rata tahap pengukuran awal yang ditunjukkan oleh adanya selisih skor antara kelompok eksperimen dan kelompok kontrol sebesar 1,07 dimana nilai rata-rata kelompok eksperimen lebih unggul. Sedangkan pada tahap pengukuran akhir juga terdapat perbedaan nilai rata-rata yang ditunjukkan adanya selisih skor antara kelompok eksperimen dan kelompok kontrol sebesar 3,81 dimana nilai rata-rata kelompok eksperimen lebih unggul.

Apabila dilihat dari hasil pengukuran pada tahap awal dan akhir, maka dapat diketahui gain score yang diperoleh yaitu sebesar 11,41 untuk kelompok eksperimen dan 8,67 untuk kelompok kontrol. Secara ringkas deskripsi komparasi hasil pengukuran tersebut dapat dilihat pada gambar 2 berikut.

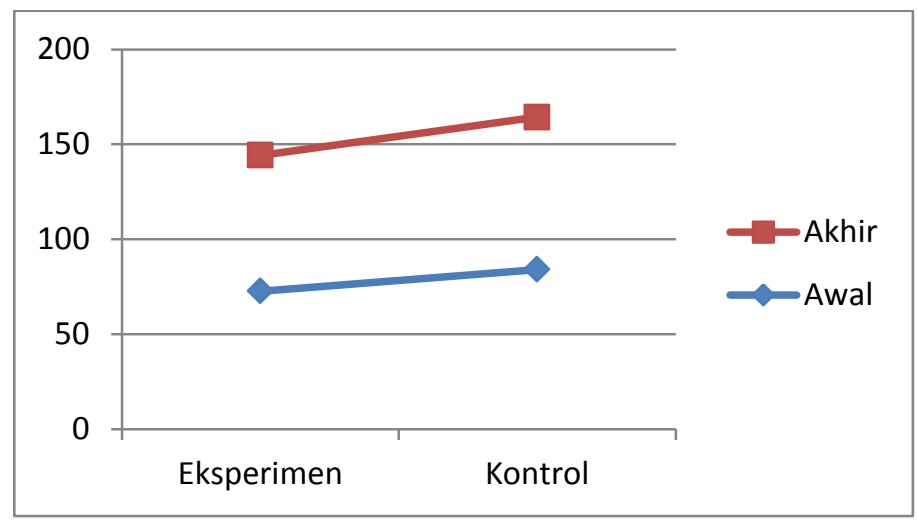

Gambar 2. Grafik Deskripsi Komparasi Hasil Pengukuran Kelompok Eksperimen dan Kelompok Kontrol SD Imbas Gugus Mawar 


\section{Hasil Uji Perbedaan Rerata Hasil Belajar Menggunakan Model Picture and Picture dan Make a Match}

Dalam hasil uji beda penelitian ini dipaparkan mengenai teknik analisis data yang digunakan yaitu uji prasyarat dan uji hipotesis. Uji prasyarat terdiri atas uji normalitas dan homogenitas. Uji normalitas yang sudah dilakukan menunjukkan bahwa nilai asymp. Sig. (2-tailed) hasil pretest-posttest kelompok eksperimen adalah 0,481 dan 0,483 . Sedangkan hasil pretest-posttest kelompok kontrol adalah 0,993 dan 0,580. Karena nilai signifikansi/probabilitas data-data tersebut $>0,05$ maka dapat disimpulkan bahwa populasi data hasil pretest-posttest kelompok eksperimen dan kelompok kontrol SD Inti berdistribusi normal.

Selanjutnya uji normalitas pada SD Imbas menunjukkan bahwa nilai asymp. Sig. (2-tailed) hasil pretest-posttest kelompok eksperimen adalah 0,846 dan 0,721. Sedangkan hasil pretest-posttest kelompok kontrol adalah 0,170 dan 0,877. Karena nilai signifikansi/probabilitas data pretest-posttest kelompok eksperimen dan kelompok kontrol tersebut > 0,05 maka dapat disimpulkan bahwa populasi data hasil pretest-posttest kelompok eksperimen dan kelompok kontrol SD Imbas berdistribusi normal.

Setelah syarat uji normalitas berupa distribusi kenormalan data terpenuhi, kemudian dilanjutkan syarat kedua yaitu tentang homogenitas atau tingkat kesetaraan data dengan melakukan uji homogenitas menggunakan Levene Test dengan ketentuan apabila nilai probabilitas/signifikansi > 0.05 maka dapat dikatakan bahwa populasi data memiliki varian yang sama atau dengan kata lain data homogen.

Setelah dilakukan uji homogenitas menunjukkan bahwa hasil output test of homogeneity of variance nilai pretest menunjukkan angka signifikansi yang ada adalah untuk probabilitas based on mean $=0,123$, untuk based on median $=0,231$, probabilitas based on median ang with adjusted $d f=0,232$ dan probabilitas based on trimmed mean $=0,122$. Sehingga dapat dikatakan bahwa data nilai pretest kelompok eksperimen dan kelompok kontrol SD Inti memiliki varian yang sama atau homogen, karena nilai probabilitas populasi data $>0,05$.

Sedangkan untuk nilai posttest menunjukkan bahwa angka signifikansi yang diperoleh adalah untuk probabilitas based on mean $=0,065$, untuk based on median $=0,096$, probabilitas based on median ang with adjusted $d f=0,097$ dan probabilitas based on trimmed mean $=0,079$. Karena nilai probabilitas populasi data $>0,05$ maka dapat dikatakan bahwa data nilai posttest kelompok eksperimen dan kelompok kontrol SD Inti memiliki varian yang sama atau homogen. Sehingga dapat disimpulkan bahwa populasi data nilai pretest-posttest kelompok eksperimen dan kelompok kontrol SD Inti memiliki varian yang sama atau homogen. 
Setelah dilakukan uji homogenitas yang menunjukkan bahwa hasil output test of homogeneity of variance nilai pretest menunjukkan angka signifikansi yang ada adalah untuk probabilitas based on mean $=0,647$, untuk based on median $=$ 0,772 , probabilitas based on median ang with adjusted $d f=0,772$, dan probabilitas based on trimmed mean $=0,668$. Sehingga dapat dikatakan bahwa data nilai pretest kelompok eksperimen dan kelompok kontrolSD Imbas memiliki varian yang sama atau homogen, karena nilai probabilitas data $>0,05$.

Nilai posttest menunjukkan bahwa angka signifikansi yang diperoleh adalah untuk probabilitas based on mean $=0,260$, untuk based on median $=0,361$, probabilitas based on median ang with adjusted $d f=0362$, dan probabilitas based on trimmed mean $=0,270$. Karena nilai probabilitas populasi data $>0,05$ maka dapat dikatakan bahwa data nilai posttest kelompok eksperimen dan kelompok kontrol memiliki varian yang sama atau homogen. Sehingga dapat disimpulkan bahwa data nilai pretest-posttest kelompok eksperimen dan kelompok kontrol memiliki varian yang sama atau homogen.

Berdasarkan hasil dari uji normalitas yang menunjukkan bahwa persebaran data posttest berdistribusi normal dan uji homogenitas yang menunjukkan bahwa data posttest homogen, maka dengan demikian uji prasyarat telah terpenuhi sehingga populasi data posttest tersebut dapat dikenakan untuk uji t (uji beda ratarata) sebagai acuan menguji hipotesis yaitu ada/tidak perbedaan rata-rata nilai posttest yang signifikan antara kelompok eksperimen dan kelompok kontrol.

Tabel 1 berikut dapat disajikan uji $\mathrm{t}$ (uji beda rata-rata) kelompok eksperimen dan kelompok kontrol.

Tabel. 1 Hasil Uji t Nilai Posttest

Kelompok Eksperimen dan Kelompok Kontrol

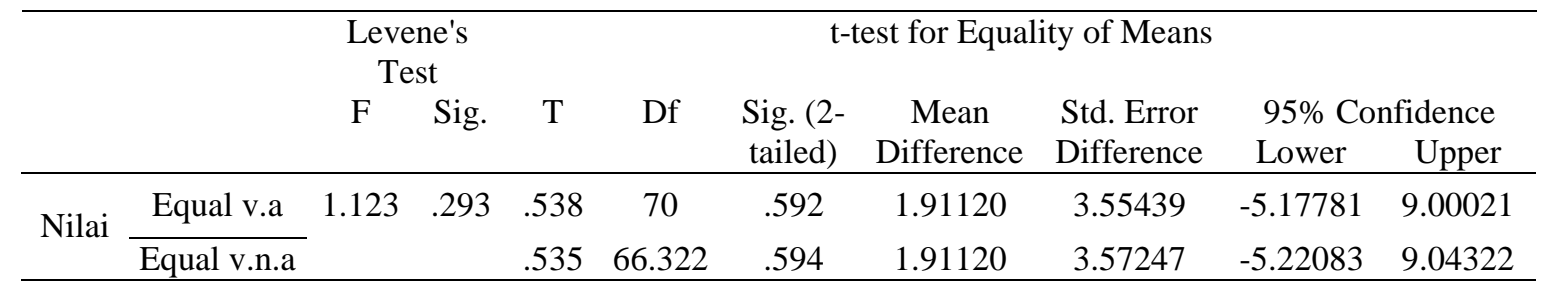

Analisis uji beda t-test menggunakan equal variances assumed (asumsi varian sama). Dari tabel di atas dapat dilihat bahwa nilai t hitung adalah 0,538 dengan sig. (2-tailed) 0,592. Tidak berbeda dengan hasil uji t yang diolah dengan bantuan ms. Excel, diperoleh nilai $t$ hitung adalah 0,538 dan $\mathrm{t}$ tabel 1,994. Nilai probabilitas > 0,05 maka $\mathrm{H}_{0}$ diterima dan $\mathrm{H}_{\mathrm{a}}$ ditolak dapat dikatakan juga bahwa tidak terdapat perbedaan yang signifikan pada hasil posttest kelompok eksperimen 
dan kelompok kontrol. Selain uji t posstest, dilakukan juga uji t dari gain score kelompok eksperimen dan kontrol. Dari hasil uji gain score diperoleh data bahwa nilai thitung adalah $-0,411$ dengan sig. (2-tailed) 0,682 . Tidak berbeda dengan hasil uji t yang diolah dengan bantuan ms. Excel, diperoleh nilai t hitung adalah $-0,411$ dan $\mathrm{t}$ tabel 1,995 . Nilai probabilitas $>0,05$ maka $\mathrm{H}_{0}$ diterima dan $\mathrm{H}_{\mathrm{a}}$ ditolak dapat dikatakan juga bahwa tidak terdapat perbedaan yang signifikan pada gain score kelompok eksperimen dan kelompok kontrol.

\section{Hasil Uji Hipotesis}

Hasil uji t (uji beda rata-rata) terhadap nilai posttest kelompok eksperimen dan kelompok kontrol dapat dijadikan acuan untuk menguji hipotesis. Hipotesis yang telah dirumuskan adalah sebagai berikut.

1. $\mathrm{H}_{0}$ : Tidak terdapat perbedaan hasil belajar yang signifikan dalam penerapan model pembelajaran Picture and Picture dan Make a Match ditinjau dari hasil belajar IPA siswa kelas 4 SD Gugus Mawar Suruh.

2. $\mathrm{H}_{\mathrm{a}}$ : Terdapat perbedaan hasil belajar yang signifikan dalam penerapan model pembelajaran Picture and Picture dan Make a Match ditinjau dari hasil belajar IPA siswa kelas 4 SD Gugus Mawar Suruh.

Berdasarkan uji t (uji beda rata-rata) yang telah dilakukan terhadap nilai posttest kelompok eksperimen dan kontrol, diperoleh hasil yaitu nilai $t$-test sebesar 0,538 dengan sig. (2-tailed) 0,592. Karena angka probabilitas menunjukkan nilainya > 0,05 maka $\mathrm{H}_{0}$ diterima yaitu tidak terdapat perbedaan hasil belajar yang signifikan dalam penerapan model pembelajaran Picture and Picture dan Make a Match ditinjau dari hasil belajar IPA siswa kelas 4 SD Gugus Mawar Suruh.

\section{SIMPULAN DAN SARAN}

\section{Simpulan}

Berdasarkan hasil analisis dan pembahasan yang telah dilakukan pada bab sebelumnya, penelitian yang dilakukan adalah penelitian eksperimen jenis quasi experiment dengan desain Nonequivalent Control Group Design. Hasil uji kesetaraan pada kelompok eksperimen dan kelompok kontrol menunjukkan adanya kesamaan atau setara. Teknik pengumpulan data menggunakan tes dan observasi. Populasi pada penelitian ini adalah gugus Mawar Suruh dan sampelnya siswa kelas 4 SDN Plumbon 01, SDN Plumbon 04, dan SDN Kebowan 02. Teknik analisis data yang dipakai untuk menguji skor hasil belajar siswa adalah uji t dengan teknik Independent Sample T Test.

Hasil penelitian yang telah dilakukan menunjukkan bahwa tidak terdapat perbedaan yang signifikan model pembelajaran Picture and Picture dan Make a Match ditinjau dari hasil belajar IPA pada SD gugus Mawar Suruh. Hal tersebut 
Keefektifan Model Pembelajaran Picture And Picture dan Make A Match ditinjau dari Hasil Belajar dalam Pembelajaran IPA Kelas 4 SD Gugus Mawar - Suruh (Mawardi \& Desty Lusia Sari)

dapat dibuktikan setelah dilakukan uji t posttest yang menunjukkan bahwa nilai $\mathrm{t}$ hitung dan t tabel adalah 0,538 dan 1,994 dengan sig. (2-tailed) adalah 0,592.

\section{Saran}

Berdasarkan kesimpulan di atas, maka peneliti menyarankan beberapa hal yang perlu diperhatikan:

1. Bagi siswa:

Memberikan pengalaman belajar yang menarik dan berkesan pada siswa dengan menggunakan model pembelajaran Picture and Picture dan Make a Match.

2. Bagi guru:

Hasil dari posttest yang menunjukkan bahwa tidak terdapatnya perbedaan model Picture and Picture dan Make a Match maka guru disarankan dapat menggunakan kedua model tersebut, karena kedua model tersebut sama-sama ampuhnya.

3. Bagi sekolah:

Memberikan sumbangan yang baik pada sekolah itu sendiri dan sekolah lain pada umumnya dalam rangka meningkatkan mutu pendidikan.

4. Bagi peneliti:

Perlu diadakan penelitian lebih lanjut dengan materi lainnya menggunakan model Picture and Picture dan Make a Match. Agar peneliti lebih dapat mengetahui perbedaan yang signifikan penerapan model pembelajaran Picture and Picture dan model pembelajaran Make a Match.

\section{DAFTAR PUSTAKA}

BNSP. 2006. Pembelajaran IPA di Sekolah Dasar. Jakarta Departemen Pendidikan Nasional.

Hamdani, M. A. 2011. Strategi Belajar Mengajar. Bandung: Pustaka Setia.

Hosnan, M. 2014. Pendekatan Saintifik dan Kontekstual dalam Pembelajaran Abad 21: Kunci Sukses Implementasi Kurikulum 2013. Bogor: Galia Indonesia.

Rusman. 2011. Model-Model Pembelajaran Mengembangkan Profesionalisme Guru. Jakarta: Rajawali Pers.

Samatowa, Usman. 2010. Pembelajaran IPA di Sekolah Dasar. Jakarta Barat: PT. Indeks.

Sulistyorini, Sri. 2007. Model Pembelajaran IPA Sekolah Dasar. Yogyakarta: Tiara Wacana.

Suprijono Agus. 2009. Cooperative Learning Teori \& Aplikasi PAIKEM. Yogyakarta: Pustaka Pelajar. 
Scholaria, Vol. 5, No. 3, September 2015: 82 - 99

Susanto Ahmad. 2013. Teori Belajar dan Pembelajaran di Sekolah Dasar. Jakarta: Kencana Prenada Media Group.

Trianto. 2014. Model Pembelajaran Terpadu: Konsep, Strategi, dan Implementasinya. Dalam Kurikulum Tingkat Satuan Pendidikan (KTSP). Jakarta: Bumi Aksara. 